\title{
PENGARUH PEMBERIAN VITAMIN D3 (CALCITRIOL) TERHADAP \\ KADAR TGF ß1 DAN IL-6 PADA PASIEN PENYAKIT GINJAL KRONIK STADIUM V
}

\section{THE EFFECT OF VITAMIN D3 (CALCITRIOL) ON LEVELS TGF B1 AND IL-6 IN FIFTH GADE CHRONIC KIDNEY DISEASE PATIENTS GRADE V}

\author{
Rahma Anindita, Bambang Purwanto, Sugiarto \\ Sub Bagian Nefrologi, Bagian Ilmu Penyakit Dalam \\ FK UNS / RSUD Dr. Moewardi Surakarta \\ Korespondensi: Rahma anindita: rahmaanindita@ymail.com
}

\begin{abstract}
ABSTRAK
Penyebab utama morbiditas dan mortalitas pada pasien PGK adalah insiden kardiovaskuler yang didasari oleh proses aterosklerosis. Penurunan kadar TGF- $\beta 1$ dan IL-6 dengan kalsifikasi vaskuler yang selanjutnya berkembang menjadi plak arteriosklerotik. Vitamin D menekan pada jalur aktivasi $N F-k B$ sehingga mempunyai sifat anti inflamasi. Penelitian ini bertujuan untuk mengetahui pengaruh suplementasi vitamin D terhadap kadar TGF- $\beta 1$ dan IL-6 pada pasien penyakit ginjal kronik stadium v yang menjalani hemodialisis. Penelitian ini merupakan penelitianeksperimen dengan randomisasi, sampel 30 orang, dibagi menjadi kelompok kontrol diberikan plasebo dan perlakuan diberikan calcitriol 1x0,5 $\mu$ g peroral selama 4 minggu. Analisis statistik menggunakan SPSS 22for windows. Karakteristik penelitian yang berupa variabel kualitatif, uji homogenitas dilakukan menggunakan uji Chi Square. Uji beda dua rerata menggunakan uji t dengan signifikansi $p<0,05$. Hasil penelitian menunjukkan pemberian calcitriol $1 x 0,5 \mu \mathrm{g}$ peroral jika dibandingkan placebo secara bermakna

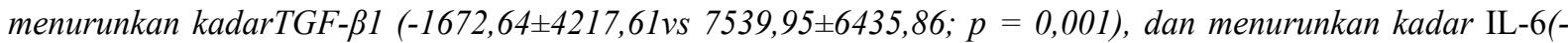
$1,45 \pm 3,14 v \mathrm{~s} 4,20 \pm 2,83 ; p=0,001)$. Pemberian suplementasi vitamin $D$ dapat menurunkan kadar TGF- $\beta 1$ dan menurunkan kadar IL-6 pada pasien penyakit ginjal kronik stadium $V$ yang menjalani hemodialisis
\end{abstract}

Kata kunci: Vitamin D, TGF- $\beta 1$, IL-6, Penyakit Ginjal Kronis

\section{ABSTRACT}

The main cause of morbidity and mortality in patients with CKD is a cardiovascular incidents based on the process of atherosclerosis. Decreased levels of TGF- $\beta 1$ and IL-6 with vascular calcification which then develops into plaque arteriosklerotik. Vitamin D suppress the activation of $N F-k B$ path so as to have anti-inflammatory properties. This study aimed to determine the effect of vitamin D supplementation on levels of TGF- $\beta 1$ and IL-6 in patients with chronic kidney disease who undergo hemodialysis $v$ stage. This study aimed to determine the effect of vitamin D supplementation on levels of TGF- $\beta 1$ and IL-6 in patients with chronic kidney disease who undergo hemodialysis $v$ stage. This study is a randomized experiment, with 30 people as a subject, divided into a control group given a placebo and the treatment group given calcitriol 1x0,5 mg orally for 4 weeks. Statistical analysis using SPSS 22for windows. Characteristics of research in the form of qualitative variables, homogeneity test was performed using Chi Square test. Two different test mean using t test $(p<0.05)$. The results showed oral administration $1 \times 0,5 \mathrm{mg}$ alcitriol when compared to placebo significantly reduced levels of TGF- $\beta 1(-1672.64 \pm$ $4217,61 v s$ 7539.95 $\pm 6435.86 ; p=0.001)$, and reduced levels of $I L-6(3,14 v s-1.45 \pm 4.20$ to $\pm 2.83 ; p=0.001)$. Vitamin D supplementation can reduce levels of TGF- $\beta 1$ and reduce levels of IL-6 in patients with stage $V$ chronic kidney disease who undergo hemodialysis

Keywords: Vitamin D, TGF- $\beta 1, I L-6$, Chronic Kidney Disease 


\section{PENDAHULUAN}

Pada tahun 2003, lebih dari 320.000 penderita PGK di Amerika Serikat menjalani dialisa dan diperkirakan akan mengalami peningkatan sampai 650.000 pada tahun 2010 dan mencapai 2 juta orang pada tahun 20130 (Nolan., 2005). Pasien PGK yang menjalani dialisis mempunyai resiko 10-30 kali lebih besar terjadi kematian karena penyakit jantung vaskuler, mereka mempunyai resiko tinggi untuk menderita penyakit jantung.Arterial Vascular Disease dan kardiomiopati adalah penyebab kematian terbesar (Sarnak et al.,2003).

Adanya inflamasi telah ditemukan dan dihubungkan dengan terjadinya penyakit vaskuler pada pasien PGK dengan hemodialisa (Kaysen., 2001). Faktor utama yang mempengaruhi terjadinya proses PJV (Penyakit Jantung Vaskular) adalah adanya inflamasi sebagai faktor yang terlibat dalam proses aterosklerosis (Stinghen dan Pecoits-Filho.,2007). Berbagai rangsangan inflamai termasuk reactive oxygen spesies (ROS) dapat mengaktivasi pelepasan sitokin proinflamasi seperti IL-1, TNF, PDGF, TGF- $\beta 1$,IL-6 yang kemudian merangsang pelepasan $\mathrm{c}$ reactive protein (CRP) dan berbagai mediator inflamasi seperti endothelial cell,tissue factor dan berbagai molekul adhesi yang berperan dalam pembentukan plak aterosklerotik.

Penurunan fungsi ginjal pada PGK akan disertai dengan penurunan produksi 1,25dihydroxyvitamin $D$, dimulai pada PGK stadium 2 yang secara progresif bertambah rendah dengan bertambahnya stadium penyakit. Penelitian epidemiologi menyebutkan bahwa rendahnya kadar 7,25- hydroxyvitamin $D$ berhubungan dengan meningkatnya resiko penyakit jantung vaskuler (Yan Chiou $\mathrm{Ku}$ et al, 2013). Penelitian lain juga menyebutkan bahwa rendahnya kadar vitamin D pada pasien PGK baik pre-dialisis maupun yang menjalani dialisis berhubungan erat dengan peningkatan mortalitas dan kejadian kardiovaskuler (Pilz S et al, 2011)

Transforming growth factor $\beta 1$ (TGF- $\beta 1$ ) adalah sitokin profibrotik pada penyakit ginjal kronis, yang memulai dan memodulasi berbagai proses patofisiologi. Transforming growth factor $\beta 1$ (TGF- $\beta 1$ ) memiliki peran besar dalam pengendalian autoimunitas.TGF- $\beta 1$ disintesis oleh berbagai jenis sel ginjal dan aktivitas fungsi biologisnya melalui berbagai jalur, termasuk jalur Smad dan MAPK (Loeffler dan Wolf, 2014). TGF- $\beta 1$ yang diekspresikan oleh sel podosit dan mesangial biasanya ditemukan di membran basalis glomerulus yang sudah matur (Jones, 2014).Pada penyakit ginjal, TGF$\beta 1$ ditingkatkan dan menginduksi sel ginjal untuk menghasilkan protein matriks ekstraselular yang menyebabkan glomerulosklerosis serta fibrosis tubulo-interstitial.Berbagai jenis sel ginjal mengalami perubahan patofisiologi yang berbeda akibat induksi TGF- $\beta 1$, yang menyebabkan apoptosis, hipertrofi dan kelainan prosesus Podosit, yang akhirnya mengakibatkan disfungsi ginjal (Loeffler dan Wolf, 2014). Disfungsi ginjal ini akan memicu terjadinya proteinuria sebagai respons tubulus ginjal yang bisa menggambarkan perkembangan penyakit ginjal.

Kadar IL-6 ditemukan meningkat pada $40-50 \%$ pasien PGK. Secara epidemiologi IL-6 terbukti sebagai prediktor yang kuat untuk terjadinya atherosklerosis pada PGK. Faktor faktor yang kemungkinan menyebabkan meningkatnya kadar IL-6 pada pasien PGK adalah hilangnya fungsi ginjal, uremia beserta komplikasinya (seperti penimbunan cairan, stress oksidatif dan kerentanan terhadap infeksi), faktor faktor yang berkaitan dengan proses dialisis itu sendiri (Stenvinkel et al, 2005). Proses hemodialisis dapat meningkatkan ekpresi dari IL-6, kemungkinan faktor-faktor yang berperan adalah membrane dialisis yang tidak biokompetible, penggunaan cairan dialisat yang tidak steril. Oleh Caglar et al dilaporkan terjadinya peningkatan kadar IL-6 dua jam setelah proses hemodialisa selesai, di mana hal ini membuktikan bahwa pada proses hemodialisa terjadi HDinduced delayed inflammatory response (Stenvinkel et al, 2005).

Penelitian ini bertujuan untuk Membuktikan, mengetahui dan membandingkan pengaruh pemberian Vitamin D3 (calcitriol) terhadap ekspresi TGF- $\beta 1$ dan IL-6 pada pasien PGK stadium $V$ yang menjalani hemodialisa.

\section{METODE PENELITIAN}

Jenis penelitian ini adalah uji klinis dengan randomized double blind controlled trial, dilakukan di instalasi hemodialisa RSUD Dr. Moewardi Surakarta pada bulan februari s.d maret 2015. Melibatkan 30 pasien PGK stadium V dengan kriteriainklusi Pasien sudah tegakdiagnosis PGK stadium $\mathrm{V}$ yang dibuktikan dengan pemeriksaan 
USG ginjal, laboratorium darah dan pemeriksaan urin memenuhi kriteria K/ DOQI 2006, Usia 20-59 tahun, telah menjalani hemodialisis satu sampai dua kali seminggu selama lebih dari tiga bulan dan kurang dari 5 tahun, tensi sistolik lebih dari 100 $\mathrm{mmHg}, \mathrm{Hb}$ lebih dari $6 \mathrm{mg} / \mathrm{dL}$, pasien dalam keadaan tidak mengkonsumsi suplemen Calcium ( baik berupa tablet Calcium ataupun susu tinggi Calcium). Kriteria eksklusi Pasien PGK dengan nefropati diabetik stadium V,Pasien PGK yang sedang menjalani terapi dengan steroid, Pasien PGK yang sedang menjalani terapi vitamin D, Pasien PGK stadium V dengan keganasan, Pasien PGK stadium V dengan uropati obstruktif, Pasien dalam keadaan sepsis, Pasien dalam kondisi infeksi ( dibuktikan dengan suhu tidak lebih dari $37,5^{\circ} \mathrm{C}$ ), didapatkan aritmia jantung, tidak menderita hepatitis $\mathrm{B}$ dan $\mathrm{C}$ kronik.

Pasien dibagimenjadi dua kelompok menggunakan metode simple random sampling dengan Open Epi versi 2.3 menjadi kelompok kontrol sebanyak 15 pasien yang diberikan plasebo dan kelompok perlakuan sebanyak 15 pasien yang diberikan vitamin D $0,5 \mu \mathrm{g} /$ hari selama 4 minggu. Selama penelitian berlangsung, regimen terapi pasien tidak dirubah dan dikontrol tiap dua minggu untuk menilai ketaatan minum obat serta mencari efek samping yang mungkin timbul.

Prinsip pemeriksaan IL-6 dengan menggunakan tehnik sandwich enzyme immunoassay : sampel direaksikan dengan antibodi monoklonal yang spesifik untuk IL-6 yang kemudian IL-6 akan terikat dengan antibodi yang termobilisasi

Data disajikan dalam bentuk mean $\pm S D$ kemudian dianalisis menggunakan SPSS 17 for windows dengan nilai $\mathrm{p}<0,05$ dianggap signifikan secara statistik. Digunakan uji beda mean. Untuk mengetahui beda mean antara kelompok perlakuan dan kontrol sebelum dan sesudah perlakuan digunakan uji t sampel independen bila distribusi data normal (bila tidak normal digunakan uji mann whitney). Untuk mengetahui beda mean antara sebelum dengan sesudah perlakuan dalam satu kelompok digunakan uji $\mathrm{t}$ sampel berpasangan bila distribusi data normal (bila tidak normal digunakan uji wilcoxon).

\section{HASIL DAN PEMBAHASAN}

Karakteristik dasar subyek penelitian dan uji homogenitas dapat dilihat pada tabel 1. Berdasarkan data tersebut tampak bahwa karakteristik dasar subyek penelitian pada kelompok kontrol dan kelompok perlakuan adalah homogen

Tabel 1. Karakteristik subyek penelitian

\begin{tabular}{lcccccc}
\hline \multirow{2}{*}{ Variabel } & \multicolumn{2}{c}{ Kontrol } & \multicolumn{2}{c}{ Perlakuan } & \multicolumn{2}{c}{ Uji Beda 2 Mean } \\
& $\begin{array}{c}\text { Rata- } \\
\text { rata }\end{array}$ & $\begin{array}{c}\text { Std } \\
\text { Deviasi }\end{array}$ & $\begin{array}{c}\text { Rata- } \\
\text { rata }\end{array}$ & $\begin{array}{c}\text { Std } \\
\text { Deviasi }\end{array}$ & $\begin{array}{c}\text { Nilai } \\
\text { Statistik }\end{array}$ & P value \\
\hline Lama HD & 1,34 & 1,00 & 2,38 & 2,05 & $\mathrm{Z}=-1,572$ & 0,125 \\
Sistole & 153,08 & 20,16 & 156,15 & 22,56 & $\mathrm{t}=-0,367$ & 0,717 \\
Diastole & 93,08 & 7,51 & 93,85 & 8,70 & $\mathrm{Z}=-0,118$ & 0,920 \\
Berat Badan & 54,00 & 7,67 & 55,92 & 10,93 & $\mathrm{t}=-0,519$ & 0,608 \\
$\mathrm{Hb}$ & 9,17 & 1,03 & 9,72 & 0,91 & $\mathrm{t}=-1,452$ & 0,159 \\
AL & 7,38 & 1,17 & 7,65 & 0,83 & $\mathrm{t}=-0,695$ & 0,493 \\
ureum & 129,62 & 45,47 & 131,69 & 61,62 & $\mathrm{t}=-0,098$ & 0,923 \\
Creatinin & 10,76 & 2,02 & 11,05 & 4,93 & $\mathrm{t}=-0,199$ & 0,844 \\
Kalsium & 1,01 & 0,07 & 0,99 & 0,08 & $\mathrm{Z}=-0,594$ & 0,579 \\
Albumin & 3,78 & 0,21 & 3,75 & 0,26 & $\mathrm{t}=0330$ & 0,744 \\
GDS & 132,31 & 17,43 & 138,77 & 16,97 & $\mathrm{t}=-0,958$ & 0,348 \\
Vitamin_D & 17,80 & 7,15 & 13,86 & 3,81 & 1,752 & 0,092 \\
\hline Keterangan: *) Signifikan pada derajat signifikansi 5 persen $(\mathrm{p}<0,05)$.
\end{tabular}

Hasil pengujian beda 2 mean kelompok kontrol dan perlakuan untuk variabel kadar TGFB1 dan IL-6 pada kondisi sebelum perlakuan pemberian Vitamin D3 (Calcitriol) menunjukkan hasil pengujian yang tidak signifikan pada derajat signifikansi 5 persen $(p>0,05)$. Dengan demikian variable TGFB1 dan IL-6 untuk kelompok kontrol dan perlakuan pada kondisi sebelum perlakuan pemberian Vitamin D3 (Calcitriol) tidak berbeda secara meyakinkan.

Tabel 2. Perbandingan Kadar TGFB1 dan IL-6 Kelompok Kontrol dan Perlakuan pada Kondisi Sebelum Perlakuan

\begin{tabular}{|l|c|c|c|c|c|c|}
\hline \multirow{3}{*}{ Variabel } & \multicolumn{2}{|c|}{ Kontrol } & \multicolumn{2}{c|}{ Perlakuan } & \multicolumn{2}{c|}{ Uji Beda 2 Mean } \\
\cline { 2 - 7 } & Rata-rata & $\begin{array}{c}\text { Std } \\
\text { Deviasi }\end{array}$ & Rata-rata & $\begin{array}{c}\text { Std } \\
\text { Deviasi }\end{array}$ & $\begin{array}{c}\text { Nilai } \\
\text { Statistik }\end{array}$ & P value \\
\hline TGFB1 & 28741,13 & 4824,42 & 29967,54 & 11326,44 & $\mathrm{t}=-0,359$ & 0,723 \\
\hline IL-6 & 12,40 & 4,51 & 12,42 & 5,64 & $\mathrm{t}=-0,009$ & 0,993 \\
\hline
\end{tabular}

Sumber: Data Primer 2016, diolah.

Hasil pengujian beda 2 mean kelompok kontrol dan perlakuan untuk variable kadar TGFB1 dan IL-6 pada kondisi sesudah perlakuan pemberian Vitamin D3 (Calcitriol) menunjukkan hasil pengujian yang signifikan untuk masing-masing variable dengan derajat signifikansi 5 persen $(\mathrm{p}<0,05)$. Hal itu berarti setelah mendapat perlakuan pemberian Vitamin D3 (Calcitriol) variable kadar TGFB1 pada kelompok perlakuan mengalami penurunan secara meyakinkan, demikian pula variable IL-6 pada kelompok perlakuan mengalami penurunan secara meyakinkan. 
Hasil pengujian beda dua mean kelompok kontrol dan perlakuan pada kondisi sesudah perlakuan pemberian vitamin D3 (Calcitriol) terhadap variable TGFB1 dan IL-6 adalah sebagai berikut:

Tabel 3. Perbandingan Kadar TGF- $\beta 1$ dan IL-6 Kelompok Kontrol dan Perlakuan pada Kondisi Sesudah Perlakuan

\begin{tabular}{|c|c|c|c|c|c|c|}
\hline \multirow[b]{2}{*}{ Variabel } & \multicolumn{2}{|c|}{ Kontrol } & \multicolumn{2}{|c|}{ Perlakuan } & \multicolumn{2}{|c|}{ Uji Beda 2 Mean } \\
\hline & Rata-rata & $\begin{array}{c}\text { Std } \\
\text { Deviasi }\end{array}$ & Rata-rata & $\begin{array}{c}\text { Std } \\
\text { Deviasi }\end{array}$ & $\begin{array}{c}\text { Nilai } \\
\text { Statistik }\end{array}$ & P value \\
\hline TGFB1 & 30413,77 & 6913,25 & 22427,59 & 11970,94 & $t=2,083$ & $0,048^{*}$ \\
\hline IL -6 & 13,85 & 3,97 & 8,22 & 4,17 & $\mathrm{t}=3,525$ & $0,002^{* *}$ \\
\hline
\end{tabular}

Hasil pengujian beda dua mean variabel kadar TGFB1 dan IL-6 sebelum dan sesudah perlakuan pada kelompok kontrol menunjukkan hasil pengujian yang tidak signifikan pada derajat signifikansi 5 persen ( $p>5$ persen) untuk kedua variable. Dengan demikian berarti variabel kadar TGFB1 dan IL-6 pada kelompok kontrol tidak mengalami perubahan setelah adanya perlakuan pemberian Vitamin D3 (Calcitriol).

Tabel 4. Perbandingan Kadar TGF- $\beta 1$ dan IL-6 Sebelum dan Sesudah Perlakuan pada Kelompok Kontrol

\begin{tabular}{|l|c|c|c|c|c|c|}
\hline \multirow{3}{*}{ Variabel } & \multicolumn{2}{|c|}{ Sebelum } & \multicolumn{2}{c|}{ Sesudah } & \multicolumn{2}{c|}{ Uji t Beda 2 Mean } \\
\cline { 2 - 7 } & Rata-rata & $\begin{array}{c}\text { Std } \\
\text { Deviasi }\end{array}$ & Rata-rata & $\begin{array}{c}\text { Std } \\
\text { Deviasi }\end{array}$ & $\begin{array}{c}\text { Nilai } \\
\text { Statistik }\end{array}$ & P value \\
\hline TGFB1 & 28741,13 & 4824,42 & 30413,77 & 6913,25 & $\mathrm{t}=-1,430$ & 0,178 \\
\hline IL-6 & 12,40 & 4,51 & 13,85 & 3,97 & $\mathrm{t}=-1,664$ & 0,122 \\
\hline
\end{tabular}

Pengujian beda dua mean sampel berpasangan variabel kadar TGFB1 dan IL-6 sebelum dan sesudah perlakuan pemberian vitamin D3 (Calcitriol) pada kelompok perlakuan menunjukkan hasil pengujian yang signifikan pada derajat signifikansi sebesar 5 persen $(\mathrm{p}<$ $0,05)$ untuk kedua variabel. Hal itu dapat diartikan bahwa setelah mendapatkan perlakuan pemberian vitamin D3 (Calcitriol) maka variabel kadar TGFB1 mengalami penurunan secara meyakinkan demikian pula variable IL-6 setelah diberikan vitamin D3 (Calcitriol) mengalami penurunan secara meyakinkan.

Perbandingan kadar TGFB1 dan IL-6 sebelum dan sesudah perlakuan pemberian vitamin D3 (Calcitriol) pada kelompok perlakuan adalah sebagai berikut:
Tabel 5. Perbandingan Kadar TGF- $\beta 1$ dan IL-6 Sebelum dan Sesudah Perlakuan pada Kelompok Perlakuan

\begin{tabular}{|l|c|c|c|c|c|c|}
\hline \multirow{2}{*}{ Variabel } & \multicolumn{2}{|c|}{ Sebelum } & \multicolumn{2}{c|}{ Sesudah } & \multicolumn{2}{c|}{ Uji t Beda 2 Mean } \\
\cline { 2 - 7 } & Rata-rata & $\begin{array}{c}\text { Std } \\
\text { Deviasi }\end{array}$ & Rata-rata & $\begin{array}{c}\text { Std } \\
\text { Deviasi }\end{array}$ & $\begin{array}{c}\text { Nilai } \\
\text { Statistik }\end{array}$ & P value \\
\hline TGFB1 & 29967,54 & 11326,44 & 22427,59 & 11970,94 & $\mathrm{Z}=-3,180$ & $0,001^{* *}$ \\
\hline IL-6 & 12,42 & 5,64 & 8,22 & 8,22 & $\mathrm{t}=5,353$ & $0,001^{* *}$ \\
\hline
\end{tabular}

Dari analisis di atas dapat disimpulkan bahwa pemberian vitamin D3 (Calcitriol) benar-benar dapat berpengaruh menurunkan kadar TGFB1 dan IL-6 masing-masing secara meyakinkan.

Tabel 6. Perbandingan Delta-TGF- $\beta 1$ dan Delta-il6 pada Kelompok Kontrol dan Kelompok Perlakuan

\begin{tabular}{|l|c|c|c|c|c|c|}
\hline \multirow{2}{*}{ Variabel } & \multicolumn{2}{|c|}{ Kontrol } & \multicolumn{2}{c|}{ Perlakuan } & \multicolumn{2}{c|}{ Uji Beda 2 Mean } \\
\cline { 2 - 7 } & Rata-rata & $\begin{array}{c}\text { Std } \\
\text { Deviasi }\end{array}$ & $\begin{array}{c}\text { Rata- } \\
\text { rata }\end{array}$ & $\begin{array}{c}\text { Std } \\
\text { Deviasi }\end{array}$ & $\begin{array}{c}\text { Nilai } \\
\text { Statistik }\end{array}$ & P value \\
\hline Delta-tgfbl & $+1672,64$ & 4217,61 & $-7539,95$ & 6435,86 & $\mathrm{t}=-4,317$ & $0,001 * *$ \\
\hline Delta-il6 & $+1,45$ & 3,14 & $-4,20$ & 2,83 & $\mathrm{t}=-4,819$ & $0,001 * *$ \\
\hline
\end{tabular}

Hasil perhitungan beda 2 mean dengan uji $t$ untuk sampel independent antara variable delta-tgfb1 kelompok kontrol dan perlakuan menunjukkan bahwa variable delta-tgfb1 itu berbeda secara meyakinkan pada derajat signifikansi 5 persen $(\mathrm{p}<0,05)$. Demikian pula hasil perhitungan beda 2 mean dengan uji t antara variabel delta-il6 kelompok kontrol dan perlakuan menunjukkan bahwa variabel delta-pth itu berbeda secara meyakinkan pada derajat signifikansi 5 persen $(p<0,05)$. Sehingga dapat disimpulkan bahwa Pemberian Vitamin D3 (Calcitriol) menurunkan kadar TGFB1dan IL-6 pada pasien PGK stadium V.

Vitamin D3 (calcitriol)akan menginduksi

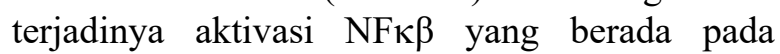
makrofag intraperitoneal untuk memproduksi sitokinproinflamasi.SitokinIL-6akanmenginduksi endotelin, endotelin akan mengaktifkan NADPH dan terbentuklah ROS. Selain itu, TNF- $\alpha$ juga akan mengaktifkan NADPH untuk membentuk ROS.

Aktivasi NFк $\beta$ juga akan meningkatkan produksi faktor pertumbuhan termasuk TGF- $\beta$. TGF- $\beta$ lakan merangsang sel target, yaitu sel fibroblas, sel mesangial, podosit, sel tibulus dan sel endotel. Aktivasisel-sel target ini akan 
memicu terbentuknya ECM. Sel fibroblas akan mengekspresikan kolagen tipe-I dan akhirnya menyebabkan terjadinya fibrosis interstisial pada ginjal. Sedangkan sel mesangial yang terletak pada glomerulus akan mengekspresikan kolagen tipe-IV, selanjutnya akan menyebabkan terjadinya glomerulosklerosis (Loeffler dan Wolf, 2014). Aktivasi TGF- $\beta 1$ pada sel podosit, menyebabkan produksi ECM, abnormalitas prosesus podosit, apoptosis sel, dan transisi sel epitel menjadi mesensimal, selanjutnya menyebabkan terjadinya glomerulosklerosis. TGF- $\beta 1$ juga akan mengaktivasi sel endotel untuk memproduksi ECM, proliferasi sel, apoptosis sel dan transisi sel endotel menjadi mesensimal, selanjutnya menyebabkan terjadinya glomerulosklerosis dan fibrosis interstisial pada ginjal. Aktivasi TGF- $\beta 1$ pada sel tubulus ginjal, menyebabkan produksi ECM, proliferasi sel, apoptosis sel dan transisi sel epitel menjadi mesensimal, selanjutnya menyebabkan terjadinya fibrosis interstisial pada ginjal. Produksi TNF- $\alpha$, juga akan menyebabkan terjadinya apoptosis yang berlebihan dari sel mesangial, podosit, sel tubulus dan sel endotel (Loeffler dan Wolf, 2014).

Reaksi inflamasi dapat menimbulkan aktivasi makrofag, selanjutnya $\mathrm{Nf \kappa B}$ menjadi lebih aktif sehingga akan mengekspresikan sitokin-sitokin pro-inflamasi antara lain TNF- $\alpha$, IL-1 maupun IL-6. Selain itu juga akan mengekspresikan TGF- $\beta 1$.

Pemberian terapi dengan Vitamin D pada penelitian ini berperan sebagai anti ROS.Vitamin $\mathrm{D}$, selain dikenal memiliki peran penting dalam metabolisme mineral tulang, juga berperan dalam berbagai fungsi biologis tubuh yang lain, diantaranya dalam sistem imun, sistem kardiovaskular, sistem reproduksi dan resistensi insulin.Vitamin D juga diketahui memiliki efek renoprotektif.

Secara keseluruhan manfaat dari penelitian ini adalah Pemberian Vitamin D3 (calcitriol)akan berpengaruh terhadap ekspresi TGF- $\beta 1$ dan IL-6. Hal ini dapat dilhat dari pemberian vitamin D3 (calcitriol) secara peroral dengan dosis $4,7 \mathrm{mg} /$ hari dalam waktu dua puluh delapan hari menurunkan ekspresi TGF- $\beta 1$ dan IL-6 pada pasien penyakit ginjal kronis stadium V secara statistik bermakna secara signifikan Sehingga dapat dipertimbangkan penggunaan Vitamin D3 (calcitriol) sebagai salah satu terapi tambahan atau suplementasi pada peningkatan outcome pasien gagal ginjal kronik guna menurunkan risiko morbiditas dan mortalitas. Keterbatasan penelitian ini adalah:

1. Penelitian ini hanya melibatkan satu center dengan subyek penelitian dan jangka waktu penelitian yang terbatas.

2. Penggunaan obat rutin yang berbeda-beda pada masing-masing subyek penelitian tidak dapat diseragamkan, sehingga tidak diketahui apakah terdapat pengaruh antara obat-obatan yang dikonsumsi pasien terhadap penyerapan vitamin $\mathrm{D}$.

3. Penelitian ini memerlukan gradasi dosis vitamin $\mathrm{D}$, dalam hal ini dosis calcitriol, dimana perlu disesuaikan dengan level kadar serum vitamin D pada masingmasing individu, apakah termasuk dalam kelompok defisiensi vitamin D (kadar serum vitamin $\mathrm{D}<20 \mathrm{ng} / \mathrm{ml}$ ) ataukah masuk dalam kelompok insuffisiensi vitamin D (kadar serum vitamin $\mathrm{D}<30 \mathrm{ng} / \mathrm{ml}$ ), untuk mendapatkan dosis yang paling tepat.

\section{SIMPULAN}

1. Pemberian Vitamin D3 (calcitriol) berpengaruh terhadap penurunan ekspresi TGF- $\beta 1$ pada pasien gagal ginjal kronis stadium V secara bermakna

2. Pemberian Vitamin D3 (calcitriol) berpengaruh terhadap penurunan kadar IL-6 pada pasien gagal ginjal kronis stadium $\mathrm{V}$ secara bermakna

\section{DAFTAR PUSTAKA}

Jones G. 2007. Expanding role for vitamin D in chronic kidney disease: importance of blood 25-OH-D levels and extra-renal lalpha-hydroxylase in the classical and nonclassical actions of lalpha,25dihydroxyvitamin D (3). Semin Dial, 20:316-24

Kaysen GA, 2001, The microinflammatory state in uremia: causes and potential consequences. J Am Soc Nephrol. 12(7):1549-57.

Loeffler, I.; Wolf, G. 2014, Transforming growth factor-beta and the progression of renal disease. 
Nephrol. Dialysis Transplant.29 (Suppl 1), i37-i45.

Nolan CR, Qunibi WY. 2005, Treatment of hyperphosphatemia in patients with chronic kidney disease on maintenance hemodialysis. Kidney Int, Suppl. (95):S13-20

Pilz S, lodice S, Zittermann A, Grant WB, Gandini S. 2011. Vitamin D status andmortality risk in CKD: a metaanalysis of prospective studies. Am J Kidney Dis; 58:374-82; PMID:21636193

Sarnak MJ, Levey AS, Schoolwerth AC, Coresh J, Culleton B, Hamm L, et al. 2003.Kidney Disease as a Risk Factor for Development of Cardiovascular Disease.Circulation. 108: pp 2154-69.

Stevinkel P, Carrero J, Axelsson J, Lindholm B, Heimburger O, Massy Z. 2008.Emerging biomarkers for evaluating cardiovascular risk in the chronic kidney disease patient: how do new pieces fit into the uremic puzzle ?Clin J Am Soc Nephrol.3:505-21

Yan Chiou Ku, Mu En Liu, Chang Sheng Ku, Shoa L. 2013. Relationship Between Vitamin D Defficiency and Cardiovascular Disease.World J Cardiol.5(9): pp 337-46. 